\title{
The Changes of Ergonomics in Hungary and Engineering Education
}

\author{
http://dx.doi.org/10.3991/ijep.v3i1.2335 \\ I. Lükő \\ University of Pécs, Pécs, Hungary
}

\begin{abstract}
Modern engineer training is not conceivable without knowledge of work psychology and ergonomics. In this paper, we would like to outline the situation of work psychology and ergonomics as well as their changes in Hungary. The technical approach to health and safety is linked to human health care, and, through that, to ergonomics. The traditional notion of ergonomics is the 'ergonomics of scales, levers and pedals', which has now become a field of research helping the development of sociotechnical systems. Here, we present the developmental stages of ergonomics, divided into six periods, first, and then the relationship between environmental ergonomics and health and safety. In the last chapter, I shall expound a few details from Hungarian investigations in work psychology, as well as from the activity of prominent academic circles at certain universities.
\end{abstract}

Index Terms -Environmental protection, ergonomics, safety technology, work psychology.

\section{INTRODUCTION}

By now, work psychology and ergonomics has not only become important and part of the curriculum in higher education and vocational education, but nearly omnipresent in everyday life. Our attention is drawn to ergonomics also by such common practical problems as loss of earnings caused by health impairment, or the consumers' (users') aspects and interests in product design etc. Injuries at work and occupational diseases may jeopardise the economic success, or even the existence of companies. 'There are workplaces where more than half of the injuries are attributable to ergonomic shortcomings. Through a simpler application of ergonomics and giving preference to solutions tailored to the workers, one could achieve cost reduction, increase productivity and enhance the safety of workplaces.' In the study by Megyeri Miklós [1], we can read about the practical problems of product design, and we quote the introductory remark here. 'It is often mentioned that, instead of modifying and improving existing systems, ergonomic activities should be integrated in the design of products and production systems. This view appeared also in technical books and in the 1989 framework directive of the EU. The latter contains the basic requirements that the legal provisions issued by the member states of the EU must conform to. The implementation of this idea has always caused difficulties in practice. While the consumers' aspects have more and more significance in the design of products, the workers' aspects are considered only very rarely during the design process. In this regard, the aspect that comes into question the most often is that of working conditions, while the well-founded preventive methods proposed by the designer are not mentioned.

My personal motivation is fostered by our university textbook Introduction to Work Psychology and Sociology of Work [2], written at the University of West Hungary (NYME) and in 1989 at the University of Forestry and Woodworking Industry (EFE). At that time, it was not widespread in Hungary to teach work psychology as a subject by itself in engineer training. This textbook was used at two faculties (forestry engineers' and woodworking industry engineers'), which was preceded by teaching ergonomics to students of forestry, based on industrial science, and the writing of the textbook. At the University of West Hungary, we applied the Engineering Education model of IGIP in the education of engineering educators and technical trainers, and, going even beyond it, we taught Environmental Ergonomics and Work Psychology, as well. In this study, I did not perform a deeper comparative analysis of the connection between engineering education and ergonomics or the situation of its teaching, but, however, I collected a few typical phenomena and relationships. My general impression is that, even though ergonomics as a field of study became self-contained and important all over the world decades ago, its representation in the education of engineers and engineering educators is incomplete and uneven. The first technical literature of 'classical' engineering education dealt with the theoretical and practical issues of technical vocational education [3]. Here, we encounter the integration of work psychology in connection with the psychological-didactic basics indirectly. The IGIP was established in Klagenfurt in 1972 and, by now, this organisation has developed into an intercontinental network, which imparts its innovations pertaining to higher and secondary education in its crucial model of engineering education and training of engineering educators. As its member, I have attended international conferences, regional days and symposia, and read through the publications of these events regularly. The title of the 31st International Symposium of the IGIP was Engineer of the 21st Century. In Saint Petersburg, the theoretical and practical issues of modern engineering education were treated in several sub-panel sessions, and several lectures were held on ergonomics and design. In Istanbul, the 34th Symposium of the IGIP in 2005 indicated the importance of design even through its title: 'Design of Education in the 3rd Millenium. Frontiers in Engineer Education'. I highlight the following two of the several dozens of lectures: A New Alliance Between Architects and Engineers towards Sustainable Design [4], and An Experimental Study on Manpowered Vehicles in Design Education [5]. Despite all that, my opinion is that 
work psychology and ergonomics are not represented in engineering education in a systematic way, and hence I held a lecture with the title Modern Engineering Education, and Work Psychology, Ergonomics at the 6th Regional Meeting of the IGIP in Berlin [6]. Besides the pedagogic issues of engineer training, the IGIP also deals with the didactical-methodical problems regarding the training of engineering educators and, through that, vocational education. The latter area is not addressed by this organisation so strongly, though its international practice and, related to that, the teaching of ergonomics is also important here, not only in higher education.

The issues regarding the relationship between vocational education and ergonomics are often neglected in Hungarian technical literature. In the book named Szakképzés-pedagógia (Pedagogy of Vocational Education), edited by Benedek András, we can find aspects of work psychology only in the chapters $A$ tanitástanulás folyamat mérnöki szemmel (The process of teaching and learning from an engineers' viewpoint) and Kompetenciák és kvalifikációk a szakképzésben (Competences and qualifications in vocational education). Regarding qualifications in her chapter [7], Balogh Andrásné refers to Blauner, who states that flexible automation requires higher qualification today again [8]. Among the analysts of the changes in technical curricula, she refers to Joe Stakenborg, who distinguishes three generations. In third-generation curricula, emphasis is laid on the participants' self-regulatory flexible training, based on their own responsibility [9].

A further aspect for inquiry was how the teaching of ergonomics in our country is institutionalised, or, how and in what organisations ergonomics is 'pursued' (taught and researched). To sum up, we can observe that this teaching and research is taken care of in an organised and integrated way at the Institute of Applied Pedagogy and Psychology (APPI), which can be found in a leading institution of engineer training, the Budapest University of Technology (BME). This Institute, established in 2005, continued the teaching of pedagogic and psychological disciplines, performed by earlier organisations.

Based on the situation outlined above, I deem it necessary to describe the developmental phases of the study of ergonomics and its situation in Hungary in more detail.

\section{The DeVelopmental Stages OF ERGONOMICS}

\section{A. The Ergonomics of 'Levers And Scales' (1945-1960)}

The birth of ergonomics is connected to the 'engineering psychology' laboratories set up for the American navy and air force. Their main task was to provide data for the right design of the 'man-machine interface' through research. In the 1940s, laboratories for non-military purposes appeared primarily in the field of industry and transport. The first scientific body, the Ergonomics Research Society was established in 1949 in England and, then, the first manual of ergonomics was published. In the 1950s, the technical innovations of the great powers motivated by the cold war, as well as the starting 'space race' gave further impetus to ergonomics. The International Ergonomics Association was set up in 1959.

\section{B. The Application of Ergonomics in Industry (the 1960s)}

In the 1960s, ergonomics goes beyond the narrow framework of military engineering and space research. Large companies all over the world set up their 'human factors' departments. 'Human factors' are used not only in designing machines and technical devices but also in shaping the environment and optimising production systems. Its methodology becomes accomplished through the fruitful influence of system theory. Ergonomics is considered more and more as a research and practice facilitating the optimal functioning of the man-machineenvironment system. In the Scandinavian countries, the shaping of the ergonomic outlook was also influenced by physiology and sociology besides psychology. Special care was given to the research aiding the humanisation of work environment. In Hungary, this period can be regarded as the beginning of ergonomics. [10]

\section{The Third Stage of Ergonomics: Product Ergonomics Emerging in the 1970s}

In the USA and the highly developed European countries, ergonomics gradually embraces all the society. The competition in electronic industry and motor car production is more and more intensified, and ergonomics is becoming instrumental in satisfying customer demands. Through the combination of industrial design and ergonomics, a further branch of ergonomics is created: product ergonomics. It endeavors to enforce specific aspects throughout the life cycle of the product (idea, production, launching in the market and recycling). In Hungary, this decade was the boom period of ergonomics. In 1976, the post-graduate education for engineers starts at the BME and the first scientific conference is organised.

\section{The Period of Safety and Ergonomics in the $1980 \mathrm{~s}$}

In this decade, the application of ergonomics becomes rather wide-spread and it is gradually integrated into science and the consumer society. Among the influences, the dramas of the catastrophes (the accidents of the Three Mile Island nuclear plant in 1979, the pesticide plant in Bhopal, India in 1984, Chernobyl and the Challenger spacecraft in 1986) directed the attention to the important role of ergonomics. A common cause became apparent: the underestimation of the role of human factors.

Another influence on the wide-spread use of ergonomics was the unrestrained spreading of computerisation. The combination of computer and ergonomics resulted in the victory and profit surplus of user-friendly products. This brought the so-called software ergonomics into being.

\section{E. The Trends and Prospects of Development: the $1990 \mathrm{~s}$}

The tendencies in the development of ergonomics are clearly palpable from the manual by Sanders and McCormick [11]. These developmental trends are the following:

- The shifting of the focus from the ergonomics of production systems to product ergonomics

- Stronger assertion of the aspects of safety and environmental protection 
- Increased consideration for special and group demands in designing

- Computerisation creates new research demands for the application of ergonomics

- Increasing interest and participation of persons with technical qualifications in ergonomics

F. Today's Ergonomics: Analysis and Development of Socio-Technical Systems

In socio-technical systems, also person-to-person relationships have an important role besides the manmachine relationship, even from the aspect of data processing and the functioning of the complete system. Through this, socio-technical systems are more complex systems, including several persons. Some examples of such socio-technical systems, which are being examined by ergonomics today, are:

- a ship and its crew

- a process control room and the operators

- one of the producing units of a factory.

\section{ENVIRONMENTAL ERGONOMICS}

In the 1980s and 1990s, the development of ergonomics and the importance of environmental protection created an integrated approach with a new outlook, in which the levels form an interlinked system.

Today, the scope of environmental ergonomics embraces the interaction of human activity and the environment functioning as its immediate locality. Environmental ergonomics used to mean primarily the examination of the microclimate (temperature conditions, humidity, air velocity), noise conditions, vibration, lighting and air quality of the workplace. That is, it dealt with the influences affecting the sense of comfort and achievement. This, however, has been complemented with the analysis of non-labour activities, such as radiation effects, the aesthetic standard and visual culture.

This resulted in the emergence of a system with manifold interrelations, which is a multi-disciplinary study and practice, dealing with the analysis, modelling and expedient influencing of the effects of the micro-, mezzo- and macro-environmental factors that endanger the individual's health and corporal integrity. This is Health and Safety.

I think that this important field has a direct 'message' for both environmental education and vocational training [12].

Nevertheless, we try to explore the content elements and media of this Health and Safety with the help of the following figure.

The relation of Health and Safety to environmental protection is complete, as the micro-environment cannot be independent from the mezzo- and macro-environment, since these are physically interlinked systems.

This explanatory sentence is important also from the view point of environmental education, since it draws the attention, firstly, to the hierarchic relationship and linked character of the environmental components, which has also a purpose-defining (assigning) role and contentselecting function in itself. Secondly, it demonstrates how and at which points the 'technical environment' is linked to the 'non-technical' environment as well as where humans have a role in it.

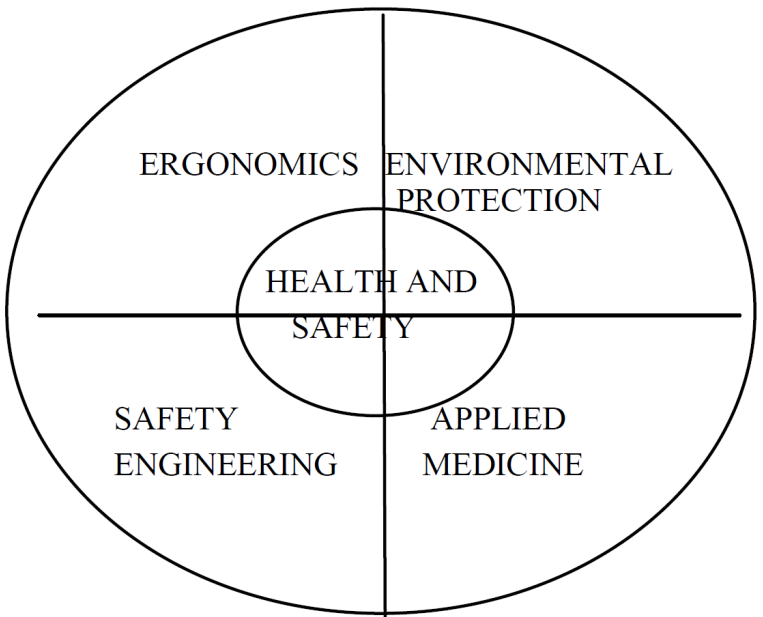

Figure 1. The relationship of Health and Safety to ergonomics, environmental protection, safety engineering and applied medicine

Here, I present the media of the 'material environment' as the elements of the safety of the environment.

On micro level, it means the prevention of contact with moving machine parts or objects under voltage,

on mezzo level, safe urban building operations, renovations, material transportation and traffic,

on macro level, safe road, rail etc. traffic, safe roads, bridges, railways, dams and dikes.

This chart with also a little hierarchy shows thus the physically linked relationship, the hidden presence of 'protection' (electric shock protection, prevention of accidents, protection against floods etc.), as well as managing quick and safe transportation.

\section{Work Psychology In Hungary}

\section{A. Facts and Figures about the History of Hungarion Work Psychology}

Before the Second World War, the presence of work psychology was not quite characteristic in Hungary. After the World War, while psychology was regarded as a 'bourgeois pseudoscience' until the 1960s, work psychology also declined and it was left out from international academic circles. [13] Owing to the reorganisation of industry and agriculture, it became necessary to direct people to the suitable position based on their knowledge, abilities and personality. In the early 1960s, large-scale workplaces (over 10000 workers) in Hungary started having work psychology laboratories, the main function of which was psychological aptitude testing. Such laboratories were set up and worked primarily in metallurgical works, textile industry and factories producing electrical devices. The reason was that, during the mechanisation of agriculture, workers contracted hearing loss, stomach complaints or spine disorders, to which the traditional approach of work psychology could not respond. The Work Psychology Department of the Institute for Psychology at the Hungarian Academy of Sciences, led by Vaszkó Mihály, adopted an ergonomic outlook in work psychology. In the 1970s and 1980s, research activities, led by Professor 
Bartha Lajos, were going on regarding 'A uniform system for the ergonomic classification of machines, equipment and technologies' within the framework of Comecon ${ }^{1}$-programme at the Psychology Department of the Institute for Teacher Training and Pedagogy at the BME [14]. Also a new occupation in automated production, the operator's work was dealt with in a separate research project at this same department. The next era consisted in the ergonomic and holistic, complex approach (human-machine-environment) to the human factor, which had changed as a result of the scientific and technical revolution, and the pioneers of that were the professors Antalovics Miklós and Kaucsek György also from the above-mentioned Institute. Besides the humanmachine interaction, also human-human interaction, that is, socio-psychological factors have an important role in the process of working, or, activity, which is properly described by the latest era of ergonomics, viz. sociotechnology, and we should mention one of its representatives in Hungary, professor Izsó Lajos, again, from the BME.

\section{B. Investigations in the Era of Traditional Work Psychology}

Here, I summarise some specific experiments in work psychology, performed by professor Klein Sándor. He taught at the Institute for Teacher Training and Pedagogy of the BME from 1964 to 1989, and then at the Faculty of Adult Education and Human Resources Development of the University of Pécs.

1) Investigation into the neuroticizing effect of mediumintensity noise

The investigations were performed on workers, punching punched cards at a data processing centre, in 1967 with 31 persons and a control group of 10 . Three kinds of examinations were performed: (1) psychophysiological examinations to establish the workers' strain and fatigue, (2) measuring of noise level, and (3) audiometry. The results of the investigations, carried out with an audiometer and an acoustic pressure measuring device, were as follows: The noise level did not reach the harmful level anywhere at the examined workplace, but it caused auditory fatigue, which ceased only at weekend breaks. It was proved that, besides the protection against noises causing substantial hearing loss, special care should be given to avoid the harmful effects of 'medium-intensity noises'.

2) Learning aptitude tests

Klein Sándor defines the term of learning aptitude tests (learners' tests) as follows: '... the primary aim of the procedure is to aid the selection of the most suitable ones (that is, the ones who will be able to acquire the most knowledge during the learning time and, then, to apply the most of that in problem-solving situations) among the pupils applying for admission to certain types of schools.' [15]

Essentially, this is a testing system that has replaced the traditional intelligence test and, thus, it is a standardised battery of questions for learners.

Omitting the procedures applied in many fields, we highlight only a few ones: the selection of trainees and

\footnotetext{
${ }^{1}$ Comecon $=$ Council for Mutual Economic Assistance
}

trainers in electric assembly, the selection of operators, and heavy equipment operators in forestry.

\section{The SHL. The Establishment of the Organisation and its Hungarian Subsidiary}

As development was going on and the role of human factors was increasing, the demand for the formation of an international network to test aptitude was growing as well. Consequently, the Saville \& Holdsworth Ltd. was set up. The Hungarian subsidiary of the aptitude-testing organisation, which was named after its founders, was launched by Klein Sándor under the name SHL Hungary Ltd. for Leadership Psychology, Manager Training and Aptitude Testing in 1992.

The competences of career orientation specialists was compiled under the leadership of professor Klein Sándor within the framework of the research project 'Evolving the competence matrix of career orientation specialists' commissioned by the National Council for Vocational Education and Adult Education with the participation of the members of the PTE FEEK ${ }^{2}$ and the ELTE $\mathrm{PPK}^{3}$ [16]. This study deals with the competences of career orientation and, generally, counselling specialists, laying, so to speak, also the taxonomic foundations of the hierarchic qualifications of psychologists and counsellors. Adopting Wiedgersma's model, the outcome of the study defines five levels for counselling activity. These are: (1) Informative counsellor, (2) Counselling in complicated decision-making, (3) Counselling in decision-making involving serious inner conflict, (4) Focal (psychological) counselling, (5) Psychotherapy.

Researchers tabulated the structure, the subcompetences as well as the knowledge, skill and attitude components of counselling competences. They also tabulated the qualifications of Hungarian counsellor training, based on their competence classifications.

\section{The activity of the Institute of Applied Pedagogy and Psychology of the BME}

The institute mentioned in the chapter INTRODUCTION works at the Budapest University of Technology and Economics (BME) and, here, we present some passages from its Organisational and Functional Rules, describing its education, research and academic instruction activity [17].

1) The objectives of the Institute regarding education: a. Concerning the activity of the Department of
Technical Pedagogy (MPT):

- in undergraduate (basic and supplementary basic) education

- training of technical and economic trainers, BSc training of specialised trainers

- university- and college-level training of technical and economic educators; MSc education

${ }^{2}$ PTE FEEK $=$ FACULTY OF ADULT EDUCATION AND HUMAN RESOURCES DEVELOPMENT OF THE UNIVERSITY OF PÉCS ${ }^{3}$ ELTE PPK $=$ FACULTY OF EDUCATION AND PSYCHOLOGY OF THE EÖTVÖS LORÁND UNIVERSITY 
- participation in undergraduate training programmes, based on agreements with other organisational units

- in graduate education

- specialised further education courses (leader in general education, special examination etc.)

- participation in graduate training programmes, based on agreements with other organisational units

- in tertiary vocational education

- vocational training courses, based on the National Training Register ('OKJ'), accredited tertiary vocational education programmes

- other training programmes:

- specialists' and other training courses, accredited further education courses for educators etc.

b. Concerning the activity of the Department of Ergonomics and Psychology (EPT):

- in undergraduate education

- teaching psychology and ergonomics in engineer training, the degree subject 'technical manager', economist training, the degree subject 'industrial designer', technical and economic educator training,

- supervising the specialisation course 'product management' in the subject 'technical manager'.

- in graduate education

- supervising the specialised further education subject 'work and organisational psychology'

- participation in graduate training programmes, based on agreements with other organisational units

2) The objectives of the Institute regarding academic instruction:

- participation in the work of the doctoral schools accredited at the BME

- participation in the work of the Doctoral School of Pedagogy and the Doctoral School of Psychology accredited at the Eötvös Loránd University

- instruction in the research methods of applied pedagogy

- instruction in the development of vocational education (especially the modernisation of training programmes and vocations) regarding content and methodology

- instruction in the human, organisational and social aspects of applying information technologies

3) The objectives of the Institute concerning research:

- Systematic academic research and development activity, conforming to the demands of theory and practice as well as to the international trends in research, in the domains of pedagogy, psychology and ergonomics to facilitate social and technical progress:

a. on the level of basic research:
- research projects in education theory;

- research projects in the methodology of education;

- research projects in information and education technology;

- research projects in distance education

b. applied research

- the development of technical and economic educator training regarding content and methodology;

- research projects for the development of vocational education in and outside of the school system, and of adult education, regarding content, methodology and education technology;

- research projects for the development of adults' vocational education;

- research projects related to the application of information technologies in educator and vocational training, and to their development;

- research projects in the theory and methodology of school management;

- research projects and model experiments in school management;

- elaborating vocational competence models

- research projects in applied psychology (especially work and organisational psychology, skills development, as well as psychological counselling)

- research projects in ergonomics (especially product and software ergonomics)

- research projects in safety science (especially product and work safety)

- research projects in the human, organisational and social aspects of applying information technologies

- Participation in research projects for the development of university (college) education, especially concerning the training of engineers, technical educators, managers and psychologists;

- R\&D activity in the topic areas falling within the domain of the Institute, within the framework of applications or contracted business undertakings;

- Augmenting and developing the project-based education and the activity of academic students' circles at the university, involving our students in the R\&D activity and the research work of the Institute;

- Operating 'academic workshops' on interuniversity, institute and department level, within the framework of the cooperation between doctoral students and young researchers connected to the Institute, as well as their consultants.

Regarding the innovations of the Department of Ergonomics and Psychology itself, we point out the empirical method Interface and the computer-aided design model Antrophos, which is applied at other universities as well. 


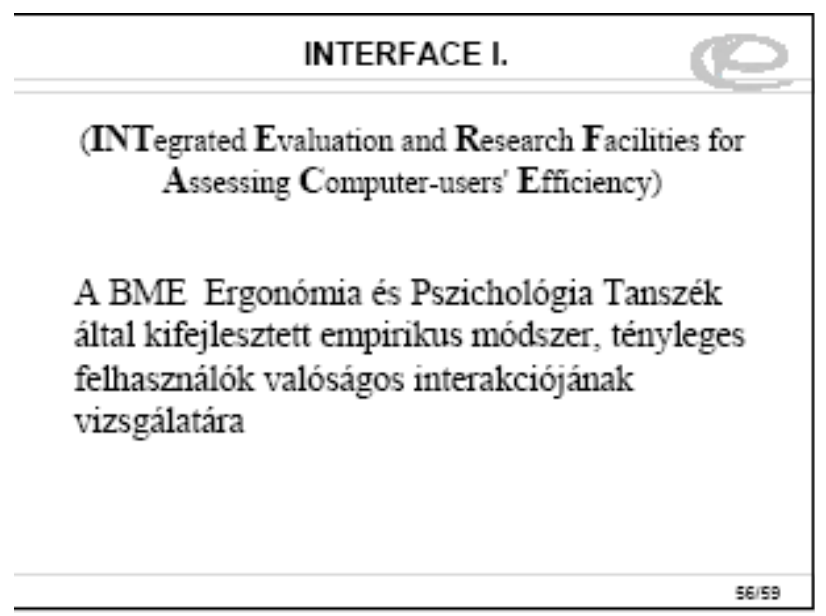

Figure 2. The INTERFACE method

\section{CONCLUSION}

The motivational background and the international perspective described in the INTRODUCTION have justified sufficiently that it is necessary to describe the changes of ergonomics and its situation in Hungary in more detail and depth. The six developmental stages of ergonomics give a clear indication of the strengthening of ergonomics and the transformation of its areas to investigate, as a result of technical development, on the one hand. New inter- and multi-disciplines came into being, such as product ergonomics, software ergonomics, environmental ergonomics etc. On the other hand, it is apparent how this field of study is organically linked to the system of psychology and the related fields.

The development of work psychology in Hungary shows that, in the period before 1989, inquiries were adapted to production at large-scale workplaces and the specific political and social circumstances. The forming of the SHL Hungary Ltd. for Leadership Psychology, Manager Training and Aptitude Testing proves, on the one hand, that the Hungarian researchers of work psychology have strong international contacts and acknowledgement and, on the other hand, that the organisation integrates aptitude testing, leadership psychology and manager training in its activity.

A still prominent venue of research and education in ergonomics and work psychology is an organisation established in the $1960 \mathrm{~s}$ at the BME. While the organisational forms were changing, the organic connection of the Department of Ergonomics and Psychology to technical educator training and engineering education has always been discernible. All that is clearly demonstrated through the activity of the Institute of Applied Pedagogy and Psychology in education, research and academic instruction and through the elaborated models.

\section{REFERENCES}

[1] Megyeri M., Az emberi tényezök és az ergonómia a termelés tervezésében [Human factors and ergonomics in the design of production], Budapest: Ergonómia, BME, 2005.

[2] Lükö I. and Pintér F., Munkapszichológia-Munkaszociológia. Egyetemi Jegyzet [Work Psychology and Sociology of Work. University Textbook], Sopron: EFE, 1990.

[3] A. Melezinek Ingenieurpädagogik Grundlage einer Didaktik des Technik Unterrichtes, Wien-New York: Springer Verlag, 1982.

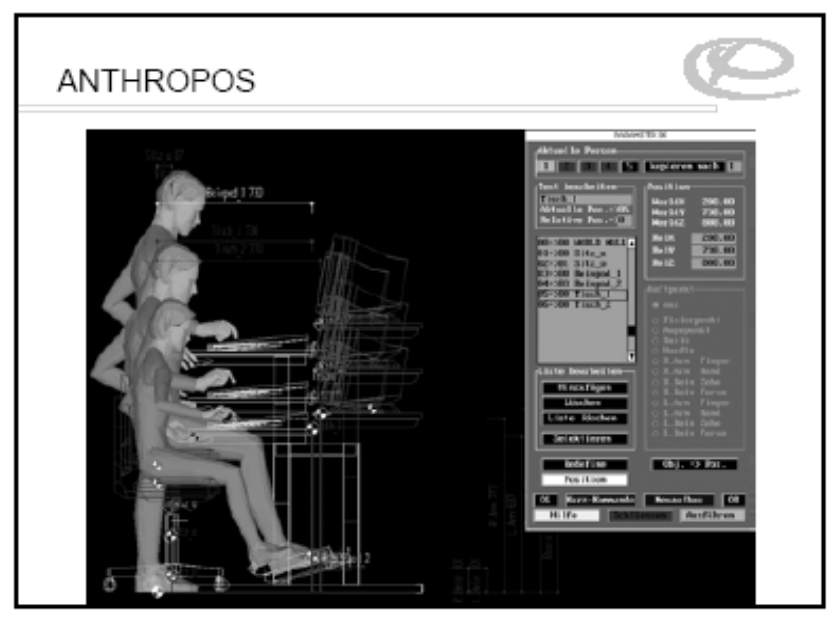

Figure 3. The essence of ANTHROPOSZ

[4] H. Gültekin, "A new alliance between architects and engineers towards sustainable design," In Procedings Design of Education in the 3rd Millenium, Vol 1, F. Flueckiger and A. Öztürk, Eds., Istanbul: IGIP- YEDITEPE UNIVERSITY, 2005.

[5] S. Satr and A. Z. Turan, "An Experimental Study on Manpowered Vehicles in Design Education," In Procedings Design of Education in the 3rd Millenium Vol 1, F. Flueckiger and A. Öztürk, Eds., Istanbul: IGIP- YEDITEPE UNIVERSITY, 2005.

[6] Lükő I., "Modern Mérnökpedagógia, és a Munkapszichológia, Ergonómia [Modern Engineering Education and Work Psychology, Ergonomics]," In 6. IGIP Regionaltagung "Renaissance der Ingenieurpädagogik - Entwicklungslinien im europäischen Raum. Dresden, Deutschland, 2011.10.272011.09.29. Dresden, Prof Dreher and Prof Niethammer, Eds., pp. $12-18$

[7] Balogh A., "Kompetenciák és kvalifikációk a szakképzésben [Competences and qualifications in vocational education]," In: Szakképzés-pedagógia [Pedagogy of Vocational Education], Benedek A., Ed., Budapest: Typotex Kiadó, 2006, pp. 68-98.

[8] Blauner, "Wandel der Qualifikationsstruktur," In: Kursmaterial: Arbeiter-organisation und Qualifikationsstruktur, Hagen: Ferullni, 1995

[9] J. Stakenborg, Competence Development as the Core Engineering Education. Fontys University of Professional Education, The Netherlands, 2005.

[10] Antalovits M., Bevezetés az ergonómiába. Oktatási segédlet [Introduction to Ergonomics. Textbook]. Budapest: BME, Department of Ergonomics and Psychology, 1994.

[11] M. S. Sanders and E. J. McCormick, Human Factors in Engineering and Design. New York: Mc Graw Hill, 1993.

[12] Lükő I., Környezetpedagógia [Environmental Pedagogy]. Budapest: Nemzeti Tankönyvkiadó, 2003.

[13] Klein S., Negyven év munkapszichológia [Forty Years of Work Psychology]. Edge $2000 \mathrm{Kft}, 2011$.

[14] Bartha L., A tudományos-technikai forradalom és az ergonómia. A KGST országok III. Nemzetközi Ergonómiai Konferenciája [The Scientific and Technical Revolution and Ergonomics. 3rd International Conference of the Comecon-Countries on Ergonomics], Budapest, 1978.

[15] Klein S., "Kísérlet egy új tipusú intelligenciateszt kialakítására [An Attempt at Elaborating a New Type of Intelligence Test]," Pszichológia a gyakorlatban [Psychology in Practice] 17. Akadémiai Kiadó, 1970, 62 pp.

[16] Muity Gy. and Nemeskéri Zs., In (2008): Pályaorientációs szakemberek kompetenciái [Competences of Career Orientation Specialists], Klein S., Ed., Pécs: PTE FEEK, Study.

[17] APPI BME SZMSZ [Institute of Applied Pedagogy and Psychology, Budapest University of Technology and Economics, Organisational and Functional Rules], 2005:

http://www.appi.bme.hu/index.php?option=com_content\&view=ar ticle\&id $=40 \&$ Itemid $=51$. 


\section{AUTHOR}

Lükő I. is a habilitated doctor, university associate professor at the Faculty of Adult Education and Human Resources Development of the University of Pécs, where he led the Centre for Vocational and Further Education between 2009 and 2012. Earlier, between 1987 and 2009, he was the head of the Vocational Teacher Training
Institute of the University of West Hungary (University of Forestry and Woodworking Industry) in Sopron. His main research areas are: the pedagogy of vocational education and environmental pedagogy.

(e-mail: sajokaza@chello.hu).

Received 30 October 2012. Published as resubmitted by the author 18 December 2012. 